\title{
Islamic View of Women Leadership as Head of the State: A Critical Analysis
}

\author{
Mohammad Elius*
}

\section{Introduction}

Since the beginning of the industrial revolution in the West, women have been given certain social, political and economic rights after decades of struggle which Islam had confirmed unequivocally fourteen hundred years ago. Islam has clarified the legal rights and obligations of both men and women in such a balanced way that women cannot complain about their weakness or inferiority and men cannot claim their superiority over women. But this position of women has been the subject to repeated controversy because of the misinterpretations of issues regarding women in our society. This paper deals with a very crucial point, women as head of the state in a Muslim/Islamic state in the light of the Holy Quran and the traditions of Prophet Muhammad (Peace be upon him). An attempt has been made to find out the real position of women vis-àvis the concept of leadership in Islam as objectively as possible to reach a balanced view. Before initiating the discussion on the main topic, that is, the leadership by women, we will give a brief description of women's position in society and their participation in public life.

\section{Position of Women in Islam}

At the dawn of Islam women were degraded, subjugated and treated as non-entities all over the world. They enjoyed very few rights and even those were at the mercy of men (Encyclopedia 1986:10). Observing this very unhappy situation the Prophet of Islam (Peace be upon him) with heavenly direction gave the women a balanced position which could not be imagined in the pre-Islamic period. As a result, women were entitled to enjoy complete freedom

\footnotetext{
${ }^{*}$ Lecturer, Department of World Religions, University of Dhaka
} 
of will as individuals and to gain their social, economic and political rights like men in a truly Islamic society. The Holy Quran treats both men and women in the same manner as individuals. The Quran states:

And their Lord hath heard them (and He saith): Lo! I suffer not the work of any worker, male or female, to be lost. Ye proceed one from another (Pickthal 3:195).

This verse makes it clear that all human beings are equal in the eye of Allah for He has the same standard of justice for all, male or female. There are many verses in the Quran which state that in the matter of reward and punishment both men and women will be treated alike as individuals and will suffer the consequence of their actions. Allah says:

And whoso doth good works, whether of male or female, and he (or she) is a believer such will enter Paradise and they will not be wronged the dint in a date-stone (Pickthal 4:124).

This is further illustrated in Surah Al-Ahzab of the Holy Quran. It says:

Lo! men who surrender unto Allah, and women who surrender, and men who believe and women who believe, and men who obey and women who obey, and men who speak the truth and women who speak the truth, and men who persevere (in righteousness) and women who persevere, and men who are humble and women who are humble, and men who give alms and women who give alms, and men who fast and women who fast, and men who guard their modesty and women who guard their modesty, and men who remember Allah much and women who remember - Allah hath prepared for them forgiveness and a vast reward (Pickthal 33:35).

All these verses mentioned above categorically say that men and women will be rewarded and punished equally for their actions. There is no discrimination between men and women in their legal rights as individuals. Thus, Islam makes it clear that in essential human dignity and fundamental rights, all human beings of whatever, race or nationality stand on the footing of equality, 
because they all ultimately sprang from a single source. The Quran says:

O mankind! Be careful of your duty to your Lord Who created you from a single soul and from it created its mate and from them twain hath spread a broad multitude of men and women (Pickthal 4:1).

\section{Women in Public Life}

In the early period of Islamic history, Muslim women enjoyed the freedom of movement and participated in many spheres of social life. They cooperated with men both in military and civil life. The freedom enabled women to develop their latent faculties. The social institutions and environment enabled them to make full use of their potentialities. That is why women excelled in the field of war, literature, oratory, public administration, music, theology (Kalam), jurisprudence (Fiqh), Hadith Studies (I'lmul Hadith), mysticism (Tasawwuf), poetry etc. As the early Muslim society gave women their fundamental rights to education and self development, many women could leave their marks on the pages of history. Of the hundreds of such illustrious women, some of them are mentioned here. For example, Ayesha (R), the wife of Prophet Muhammad (pbuh), was a lady of profound erudition. Many Sahaba (companions of the Prophet) and Tabeeyeen (direct followers of the Sahaba) used to come to her for learning Islamic law, theology and Hadith. Zainab (R), the daughter of Hazrat Ali (K), was a great Islamic scholar of theology. Fatima Binte Abbas and Sikha Sayeeda, the two Islamic scholars, used to come to the mosque regularly to deliver lectures on Islamic theology. History records the name of many female warriors who fought against the enemies in the battle fields. Even Hazrat Aisha (R) took active part in many battles. Umme Atyqah was a brave lady who accompanied the Prophet (pbuh) in seven battles. Wairyh, the sister of Muawia, led a contingent of women in the battle of Yarmuk. Muslim women also left their mark in the field of spirituality. Some prominent Sufi saints also emerged among women in the early period of Islam (Alam 1984: 305-11). 


\section{Women as Head of the State}

There are arguments both for and against the political leadership by women in Islam. Those who oppose, say that a woman cannot be the head of the state or the chief executive of a country and refer to some verses of the Holy Quran in their support which are as follows:

1. And they (women) have rights similar to those of men over them in kindness, and men are a degree above them. Allah is Mighty, Wise (Pickthal 2: 228).

2. And call to witness, from among your men, two witness. And if two men be not (at hand) then a man and two women, of such as ye approve as witness, so that if the one erreth (through forgetfulness) the other will remember (Pickthal 2:282).

3. Men are the protectors and maintainers of women, because Allah has given the one more (strength) than the other, and because they support them from their means. Therefore, the righteous women are devoutly obedient to their husbands and guard in (the husband's) absence (Mushaf 1410H.4:34).

They also mention some traditions attributed to the Prophet (pbuh) in favour of their arguments.

1. Abu Bakra reported: when it reached the Prophet (pbuh) that the Persians had enthroned a daughter of the Kisra as queen over them, he said: "Never shall a people prosper who make a woman their ruler" (Hossain 1987:214).

2. Abu Said Al- Khudri narrated: Once Allah's Prophet (pbuh) went out to offer Eid-al-Adha or Eid-al-Fitr prayer. He passed by the women and said:

O women! Give alms, as I have seen that the majority of the dwellers of hell-fire were you (women). They asked why is it so? O Allah's Prophet!" He replied, "You curse frequently and are ungrateful to your husbands. I have not seen anyone more deficient in intelligence and religion than you. A cautious sensible man could be led astray by some of you." The woman asked, "O Allah's Prophet! 
What is the deficiency in our intelligence and religion?" He said, "Is not the evidence of two women equal to the witness of one man?" They replied in the affirmative. He said, "This is the deficiency in your intelligence. Is not it true that a woman can neither pray nor fast during her menses? They replied in the affirmative. He said, "This is the deficiency in your religion (Khan 1984:181).

Those who support the proposition that a woman can become the head of a Muslim state or chief executive refer to the following verses of the holy Quran:

1. And covet not the thing in which Allah hath made some of you excel others. Unto men a fortune from that which they have earned, and unto women a fortune from that which they have earned. (Envy not one another) but ask Allah of His bounty. Lo! Allah is ever Knower of all things (Pickthal 4:32).

2. And the believers, men and women, are protecting friends one of another; they enjoin the right and forbid the wrong, and they establish worship and they pay the poor- due, and they obey Allah and His messenger. As for these, Allah will have mercy on them. Lo! Allah is Mighty, Wise (Pickthal 9:71).

3. ...And those who answer the Call of their Lord and establish worship, and whose affairs are a matter of counsel, and who spend of what We have bestowed on them (Pickthal 42:38).

4. (The Queen of Sheba) said (when she received the letter): O Chieftains! Lo! there hath been thrown unto me a noble letter. Lo! it is from Solomon, and lo! it is : In the name of Allah the Beneficent, the Merciful. Exalt not yourselves against me, but come unto me as those who surrender. She said: O chieftains! Pronounce for me in my case. I decide no case till ye are present with me....But lo! I am going to send a present unto them, and to see with what (answer) the messenger return (Pickthal 27:29-35).

5. He (Solomon) said: Disguise her throne for her that we may see whether she will go aright or be of those not rightly guided.... She (the Queen said: My Lord! Lo! I have wronged myself, and I surrender with Solomon unto Allah, the Lord of the worlds (Pickthal 27:41-44). 
Through all these Quranic verses and the prophetic traditions (Al Hadith) mentioned above we can easily develop some arguments for and against women as head of the state. We can also examine the arguments of both sides very carefully. Now, the arguments of those who oppose the rule of women as head of the state also include the following inferences from the following verses:

1. Though the women have similar rights as men, yet men have a degree above them (Al-Quran 2:228). Hence the argument issince the man is superior to woman; she cannot rule over men.

2. Evidence of two women is equal to that of one man (Al-Quran $2: 282$ ). So, the argument is that a woman is half of a man and she cannot rule over him.

3. Men are the protectors and maintainers of women (Al-Quran $4: 34)$. So, the argument is: If men are the protector of women, how can women rule over men?

4. When the prophet of Islam (Peace be upon him) heard that Persians had made the daughter of Kisra ruler over them, he said: Never shall a people prosper who make a woman their ruler.

5. Women lack in intelligence and their knowledge of religion. How can they conduct a state?

Now, those who say that a woman can rule a country advance the following arguments:

1. There is no verse in the Quran regarding the permission or prohibition of a woman's rule in a country. The Quran is silent on this particular point. The silence of the Quran on this crucial issue means that it has been left to the Muslim community to decide according to the circumstances.

2. The women have rights similar to those of the men (Al-Quran 2:228). If men have the right to become head of the state or government, why can't a woman aspire for this office?

3. The story of a woman ruler, Bilqis, the Queen of Sheba, has 
been related by the Quran in its chapter 27 (Sura 27). From the description of the Holy Quran, we come to notice that:

a) Her rule was not that of an autocrat. She had the very good quality of consulting others on all important affairs of the state.

b) She was a very wise woman and her sound opinion could not be ignored. Prophet Solomon (A) tested her judgment by miraculously producing her throne in a disguised form and she recognized it.

c) And on the top of all she accepted Islam when she met the Prophet Solomon (A), despite the fact that she was the ruler of disbelievers and had lived all her life among the polytheists.

4. The Quran has not talked to the rule of the Queen of Sheba with disapproval and condemnation. Rather her habit of the consulting others before taking decision on vital issues, her wisdom and sound judgment and her readiness to accept Islam at once rather than persisting in disbelief, have found special mention in the Quran.

5. According to the Holy Quran (9:71) both Muslim men and women are protecting friends of each other, they are to enjoin the right and forbid the wrong which is primarily the duty of the state and one needs to have a position to discharge it effectively. For performing this duty, Allah has made women as much protecting friends of men as men are of women. The Holy Quran directs women to discharge the duty of enjoining good and forbidding wrong which can be discharged most effectively by the ulil amr (person in authority) who symbolizes the State. The verse paves the way for the women to become the repository of state authority including the authority of the Head of the State(Usmani 1991: 258-61).

6. The functions of an Islamic state have been outlined by the Holy Quran in its verse 41 of chapter 22. These functions include establishing of prayer, collection of Zakat and enjoining good and forbidding wrong. The responsibility of discharging these functions has been laid on the shoulders of both Muslim men and women. 
7. The supporters of the women's rule does not accept as authentic the narration (riwayah) pertaining to the daughter of Kisra since its reporter Abu Bakra was found guilty of false evidence and was even punished by Hazrat Omar (R) (Choudhury 1997:172).

8. Regarding the second narration (riwayah) Maulana Abdul Halim opines that this tradition has no origin (Hossain 1987: 225). According to Nawawi, it is fabricated and false (Hossain 1987: 225). Professor Doctor Abdul Hamid Mutawali gave his opinion that this tradition is one of the many forged and fabricated traditions (Hossain 1987:221). The reasons are:

(a) It is not agreeable with human reason, logic and rationality. In fact, intelligence or rationality is not the preserve of men only. A large percentage of the male species is not intelligent enough. There may be women having more intelligence than man.

(b) The tradition is contrary to the Quran when Allah stressed that the duty to enjoin the right and forbid the wrong is of men and women alike [Q.9:71]. How can the authenticity be acknowledged when women are considered defective in reason and religion?

(c) It is contrary to the historical facts pertaining to the period of the Prophet (pbuh) and his rightly guided Caliphs (Khulafa AlRashidun). There are a number of precedents in which women were consulted or their opinions prevailed. It is widely known that Prophet Muhammad (pbuh) consulted Hazrat Umme Salma (R) on the occasion of Treaty of Hudaibia and he followed her advice. Prophet Muhammad also followed the advice of Khadija (R) at the very beginning of revelation when he was frustrated. Hazrat Aisha (R) corrected Hazrat Abu Huraira (R) in respect of traditions on the basis of their contradicting the Quran. A lady interrupted Hazrat Umar (R) successfully with regard to his proposal about fixing the dower (Mahr) at a low level. After the assassination of Hazrat Umar (R) the board appointed by him for selection of a Caliph consulted women too.

In this view of the matter it can easily be said that if there had been a defect in their intelligence women would not have been consulted by the Prophet (pbuh) and his companions nor Imam Tabari (R) and 
Imam Abu Hanifa (R) would have given opinion in favour of their appointment as judges.

\section{Views of Some Eminent Islamic Scholars}

Though majority of Islamic scholars do not support the leadership of women or women as head of the state, there are some eminent Islamic scholars who support it. Now, we would like to mention the views of some famous Islamic scholars in this context.

1. Mawlana Ashraf Ali Thanvi (R), a leading scholar of the Islamic world from India, gave a 'Fatwa' in favour of Shahjahan Begum the Queen of Bhopal. He stated that if the government is democratic and the affairs of the state are being conducted by the ruler with the help of elected representatives and in consultation with them, then there is no bar against a woman becoming the head of a state or government. He argued that in such a situation the woman ruler is in fact one of the counsels and women are eligible to give advice because the Prophet of Islam (Peace be upon him) consulted Umme Salma (R) at Hudeybia and acted upon her advice (Choudhury 1997:173).

2. Imam Malik, the founder of the Maliki school of Islamic Fiqh (jurisprudence) is reported to have opined that a woman can become head of the state in all its affairs (Choudhury 1997:147). On the basis of the opinion of Imam Malik, the Maliki jurists have also given verdicts in favour of this view (Hossain 1987:228).

3. Allama Syed Sulaiman Nadavi (R), in his book Seerat-i-Aisha (R) recognized the practical considerations in this context:

This is correct that the natural tendencies of the women make her unfit for discharging the duties of Imamat (government or chieftainship) and it is not possible for the fair sex to comply with the conditions which Islam has imposed for the governmental role. For this reason, the women are exempted from assumption of the authority of the head of the state. But from this it cannot be concluded that it is not lawful for a woman to ever lead the public politically or to assume the leadership of the army (Hossain 1987:217). 
4. Syed Sulaiman Nadvi (R), in the same book, has also mentioned that according to one version, Imam Abu Hanifa (R) and some other jurists conceded a woman's qualification to hold the office of Imam (ruler) and of a judge (Hossain 1987:126).

\section{Conclusion}

If we make a thorough examination and critical appreciation of the arguments advanced by both parties, we come to notice that none of these two parties has been able to carry their points. Arguments given in favour of the proposition and arguments given against the proposition are by and large indirect. There is no verse in the Quran which directly either permits the rule of women or prohibits it. The traditions of the Prophet Muhammad (pbuh), mentioned in this article, against women as the head of the state are believed to be unreliable and unauthentic due to many reasons. As a result, we can say without contradiction that the Quran and Sunnah (Traditions of the Prophet Muhammad (pbuh)) neither permit nor forbid the rule by women. Rather the silence of the Quran and the Hadith on this very important and vital issue is not without wisdom and sagacity. This deliberate silence means that Islam has given full freedom and direction to the Muslim community to decide on this matter according to the ever changing socio-political circumstances.

\section{References}

Alam, S. 1984, Islamic Thoughts. Dhaka: Islamic Foundation Bangladesh.

Choudhury, M. Sharif. 1997. Women's Right in Islam. Delhi: Adam Publishers and Distributors.

Encyclopedia of Seerah. 1986. London: Seerah Foundation, Vol. 11.

Hossain, J. A. 1987. Status of Women in Islam. Lahore: L awPublishing Company.

Khan, M. M. 1984. Sahih- Al- Bukhari: Arabic-English Translation. New Delhi: Kitab Bhavan. 
Mushaf Al- Madinah An- Nabawiyah, (1410H) The Holy Qur-an: English Translation of the Meanings and Commentary. The Kingdom of Saudi Arabia: King Fahd Holy Quran Printing Press.

Pickthal, M. N. D. The Meaning of The Glorious QUR'AN: Text \& Explanatory Translation. Delhi: Kutub Khana Ishyet-ul- Islam

Usmani, O. A. 1991. Fiqh ul Quran: English Translation, Vol.3 